\title{
On the Role of G Protein-Coupled Receptors Oligomerization
}

\author{
Maricel Gómez-Soler, Siobhán Ahern, Víctor Fernández-Dueñas and Francisco Ciruela* \\ Unitat de Farmacologia, Departament Patologia i Terapèutica Experimental, Facultat de Medicina, Universitat de \\ Barcelona, L'Hospitalet de Llobregat, 08907 Barcelona, Spain
}

\begin{abstract}
The existence of a supramolecular organization of the G protein-coupled receptor (GPCR) is now being widely accepted by the scientific community. Indeed, GPCR oligomers may enhance the diversity and performance by which extracellular signals are transferred to the G proteins in the process of receptor transduction, although the mechanism that underlies this phenomenon still remains unsolved. Recently, it has been proposed that a trans-conformational switching model could be the mechanism allowing direct inhibition/activation of receptor activation/inhibition, respectively. Thus, heterotropic receptor-receptor allosteric regulations are behind the GPCR oligomeric function. In this paper we want to revise how GPCR oligomerization impinges on several important receptor functions like biosynthesis, plasma membrane diffusion or velocity, pharmacology and signaling. In particular, the rationale of receptor oligomerization might lie in the need of sensing complex whole cell extracellular signals and translating them into a simple computational model.
\end{abstract}

Keywords: G protein-coupled receptor, protein-protein interaction, GPCR oligomerization.

\section{INTRODUCTION}

The starting point of the GPCR oligomerization contest dates to the beginning of the eighties when two pieces of work proposed that GPCRs could interact at the level of the plasma membrane. First, it was postulated that an intermembrane interaction between the neuropeptide and the monoamine receptors was at the forefront of the functional crosstalk observed between these two neurotransmitter systems, based on implicit functional evidence [1]. Also, in the same year it was shown that the $\beta$-adrenergic receptor agonist isoproterenol increased $\alpha_{2}$-adrenergic receptor binding in cortical slices [2]. Increased knowledge has been gained, by the use of radioligand-binding, of certain receptor-receptor interactions such as the interactions between cholecystokinin $(\mathrm{CCK})$ and dopamine $\mathrm{D}_{2}$ receptors, $\mathrm{CCKB}$ and serotonin 5$\mathrm{HT}_{2}$ receptors, neurotensin and dopamine $\mathrm{D}_{2}$ receptors, vasoactive intestinal peptide (VIP) and serotonin 5- $\mathrm{HT}_{1}$ receptors, neuropeptide Y (NPY) and $\alpha_{2}$ adrenergic receptors, and neurokinin $\mathrm{NK} 1$ and $5-\mathrm{HT}_{1}$ receptors (for review see [3]). After that, studies using photo-affinity labelling, radiation inactivation, cross-linking experiments and hydrodynamic analysis all supported the dimerization idea [4-7]. In the nineties, using electrophoretic mobility, coimmunoprecipitation and transcomplementation assays, first indications of GPCR homodimerization were encountered. By using the SDS-PAGE and Western blot approach it was possible to visualize GPCR homodimers as they were resistant to denaturing conditions (e.g. SDS and heat treatment) and receptor species of twice the expected molecular size were observed. For instance, $5-\mathrm{HT}_{1 \mathrm{~B}}, \mathrm{D}_{1}$ and $\mathrm{D}_{2}$ receptor homodimers were shown to occur in cell lines [8-13]. The

*Address correspondence to this author at the University of Barcelona, Unitat de Farmacologia, Dept. de Patologia i Terapeutica Experimental, Facultat de Medicina (Campus de Bellvitge), Pavelló de Govern, Av. Feixa Llarga, s/n, 08907 L'Hospitalet del Llobregat, Barcelona, Spain; Tel: +34 (93) 402 4280/ +34 (93) 403 5820; Fax: +34 (93) 402 9082; E-mail: fciruela@ub.edu existence of dopamine $\mathrm{D}_{2}$ and adenosine $\mathrm{A}_{1}$ receptor homodimers in the brain was demonstrated also using this approach, showing their existence in native tissue and giving, for the first time, some impending relevance of the GPCR oligomerization phenomenon under physiological conditions $[13,14]$. In the last decade the study of the quaternary structure of GPCRs in living cells has been possible because of the development of biophysical techniques based on resonance energy transfer (RET), like bioluminescenceRET (BRET) and fluorescence-RET (FRET), [3, 15-20]. Recently, the combination of RET-based methods together with bimolecular fluorescence/luminescence complementation techniques (BiFC and BiLC, respectively) as well as sequential BRET-FRET (SRET) being used as new fluorescence-based approaches have lent themselves to the identification of higher-order GPCR oligomers or receptor mosaics, helping to detect the existence of three or more receptors within the same oligomer [21-27]. Also, using some of the techniques mentioned above it was possible to isolate receptor homo- and heterodimers in order to study their distinctive pharmacodynamic properties, thus ascertaining differences between receptor dimers and protomers with a potential relevance to drug discovery investigation.

Nowadays GPCR oligomerization is becoming widely accepted as a potential target in drug discovery despite some minor controversy [28]. The combination of all the information provided by the experimental approaches described above unquestionably leads to the conclusion that GPCR oligomers exist in native tissue and that they might be relevant in normal and pathological conditions.

\section{MOLECULAR BASIS OF GPCR OLIGOMERIZA- TION}

Over the past few years, several studies of GPCR homoimerization have been focused on identifying key residua important in the phenomenon of GPCR oligomerization. It seems that the N-terminal domain disulphide bonds play an 
important role in the homodimerization of some $\mathrm{C}$ family GPCRs like the metabotropic glutamate type $5\left(\mathrm{mGlu}_{5}\right)$ receptor, the $\mathrm{mGlu}_{1 \alpha}$ receptor and $\mathrm{Ca}^{2+}$-sensing receptors. On the other hand, the C-terminal tail of another receptor of this family, namely the metabotropic $\gamma$-aminobutiric acid $(\mathrm{GABA})_{\mathrm{B}}$ receptor, drives the heterodimerization of $\mathrm{GABA}_{\mathrm{B} 1} \mathrm{R}$ and $\mathrm{GABA}_{\mathrm{B} 2} \mathrm{R}$ by means of "coiled-coil" interactions [29]. Alternatively, it seems that both intracellular and extra-cellular domains are eventually involved in the interface between some GPCR oligomers. In contrast, in studies conducted on a model of the rhodopsin dimer/ oligomer, the intradimeric contact was proposed to be located within the transmembrane helix-IV and transmembrane helix-V (TM4 and TM5, respectively) [30]. Interestingly, these results are in contrast with the pioneering studies of Hebert and his colleagues [31], where the transmembrane helix-VI (TM6) of the $\beta_{2}$-adrenergic receptor was said to participate in the homodimerization of the receptor, but they agree with the studies demonstrating that the interface of the dopamine $\mathrm{D}_{2}$ receptor homodimer is comprised within the TM4 [24, 32-34]. In addition, the participation of TM4 in the oligomer interface has been demonstrated for the serotonin $5-\mathrm{HT}_{2 \mathrm{C}}$ receptor homodimer [35], the serotonin 5- $\mathrm{HT}_{4}$ receptor homodimer [36], the chemokine CCR5 receptor homodimer [37], the $\alpha$-factor pheromone receptor (Ste2) homodimer [38], the corticotrophin releasing hormone/VT2 arginine vasotocin receptor heterodimer [39] and the serotonin $5-\mathrm{HT}_{2 \mathrm{~A}} / \mathrm{mGlu}_{2}$ receptor heterodimer [40].

Nowadays, it is well accepted and to a certain extent demonstrated that the interaction interfaces of oligomerization of the class A of GPCRs are formed by lipid-exposed surfaces within the transmembrane helical-bundle of each individual protomer (for review see [41]). Thus, it has been predicted that alterations in the receptor hydrophobic core may affect the receptor conformation and oligomerization. Interestingly, it has been recently proposed that GPCR oligomers need not be highly stable to function as oligomers [42]. This concept may make sense since transient oligomerization might allow, in theory, the exchange of protomers (i.e. during receptor activation). Of late, it has been proposed that the dynamics of oligomer association and dissociation may be subject to physiological regulation or pharmacological intervention [42]. In general, two levels of interaction could be considered within the GPCR oligomer interface: the transmembrane helices and the intra- and extracellular domains (Fig. 1); and these, rather than being exclusive, work in a coordinated manner for the oligomer stabilization and function.

Indeed, a coulombic epitope-epitope interaction for the dopamine $\mathrm{D}_{2}$ receptor $\left(\mathrm{D}_{2} \mathrm{R}\right)$ and the adenosine $\mathrm{A}_{2 \mathrm{~A}}$ receptor $\left(A_{2 A} R\right)$ has been described as a class A receptor intracellular interaction interface [43]. This interaction is based on an electrostatic attraction between a potentially phosphoryable serine/threonine domain (acidic motif) of the C-terminal tail of the $\mathrm{A}_{2 \mathrm{~A}} \mathrm{R}$ and an arginine-rich, highly conserved epitope (basic motif), located within the third intracellular loop of the $\mathrm{D}_{2} \mathrm{R}$. As a result, it can be hypothesized that phosphorylation/dephosphorylation events might regulate the oligomeric state of these receptors. In addition, it has been recently established that mutation of this serine reduces the ability of $A_{2 A} R$ to interact with the $D_{2} R$, [44] showing that the point mutation of the serine 374 in the $A_{2 A} R / D_{2} R$ eradicates the functional cross-talk observed between these two receptors when forming the heterodimer [44]. Overall, it can be suggested that by targeting the $\mathrm{A}_{2 \mathrm{~A}} \mathrm{R}$ serine 374 it will be possible to allosterically modulate $\mathrm{A}_{2 \mathrm{~A}} \mathrm{R} / \mathrm{D}_{2} \mathrm{R}$ function. This might represent a new approach to the therapeutic modulation of $\mathrm{D}_{2} \mathrm{R}$ function. On the other hand, the substitution of this serine by alanine doesn't inhibit the ability of these receptors to co-immunoprecipitate, thus suggesting that the hydrophobic transmembrane receptor-receptor interaction (see above) plays mostly a key structural role in stabilizing the oligomer at the plasma membrane level, and on the other hand the coulombic interactions within the intracellular soluble domains would play mostly a regulatory (i.e. allosterical) role in controlling the heterodimer functionality (Fig. 1).

In the same way, it has recently been demonstrated that the third intracellular loop of the muscarinic acetylcholine $\mathrm{M}_{5}$ receptor $\left(\mathrm{M}_{5} \mathrm{R}\right)$ has a regulatory responsibility in receptor function and heteromerization [45]. Thus, a peptide derived from the $\mathrm{M}_{5} \mathrm{R}$ third intracellular loop reduced the degree of heterodimerization between the $M_{5} R$ and the $M_{3} R$ and abolished the carbachol-mediated ERK1/2 phosphorylation in cells coexpressing the $M_{3} R$ and the $M_{5} R$ [45]. The expression of the $\mathrm{M}_{5} \mathrm{R}$ third intracellular loop specifically targets the $\mathrm{M}_{3} \mathrm{R} / \mathrm{M}_{5} \mathrm{R}$ heterodimeric function without affecting the individual $\mathrm{M}_{3} \mathrm{R}$ or $\mathrm{M}_{5} \mathrm{R}$ function.

Overall, it has been hypothesized that the interacting interfaces between two GPCRs in general, and the specific amino acids involved in the control of the heteromeric functionality in particular (i.e. the $\mathrm{A}_{2 \mathrm{~A}} \mathrm{R}$ serine 374 ), might act as "check-points" along the allosteric communication pathways of a named receptor-receptor interaction [46].

\section{BIOSYNTHESIS AND PLASMA MEMBRANE DIFFU- SION OF GPCR OLIGOMER}

In order to reach the cell surface, the plasma membrane proteins (i.e. GPCRs), need to pass the ER/Golgi qualitycontrol system. Consequently, only the correctly folded receptors are able to pass through this control and be trafficked to the plasma membrane [47, 48]. For many proteins, oligomeric assembly has an important influence on the ER/Golgi quality control because it can mask specific retention signals or hydrophobic patches that would otherwise retain the proteins in the ER [49]. For GPCRs, the necessity of dimerization for correct transport to the plasma membrane (Fig. 1) has been shown with the $G_{A B A} R$, which is composed of two subunits, namely $G_{A B A} R$ and $\mathrm{GABA}_{\mathrm{B} 2} \mathrm{R}[29,50-52]$. As such, $\mathrm{GABA}_{\mathrm{B} 1} \mathrm{R}$ and $\mathrm{GABA}_{\mathrm{B} 2} \mathrm{R}$ subunits interact initially in the ER and when only $\mathrm{GABA}_{B 2} \mathrm{R}$ is present $\mathrm{GABA}_{\mathrm{B} 1} \mathrm{R}$ is targeted predominantly to the cell surface [50-52]. Now, it is well established that $\mathrm{GABA}_{\mathrm{B} 2} \mathrm{R}$ is as necessary for surface trafficking as Gprotein coupling with $G_{A B A} A_{B 1} R$ is necessary for agonist activation to conform functional $\mathrm{GABA}_{\mathrm{B}} \mathrm{Rs}[29,50-58]$.

It has been shown by the combination of BiFC, which allows the detection of receptor oligomers at relatively low levels of expression, and fluorescence correlation spectroscopy (FCS) which is used to obtain quantative information such as plasma membrane diffusion or velocity of homo and oligomeric forms of some of the GPCRs, that once the 


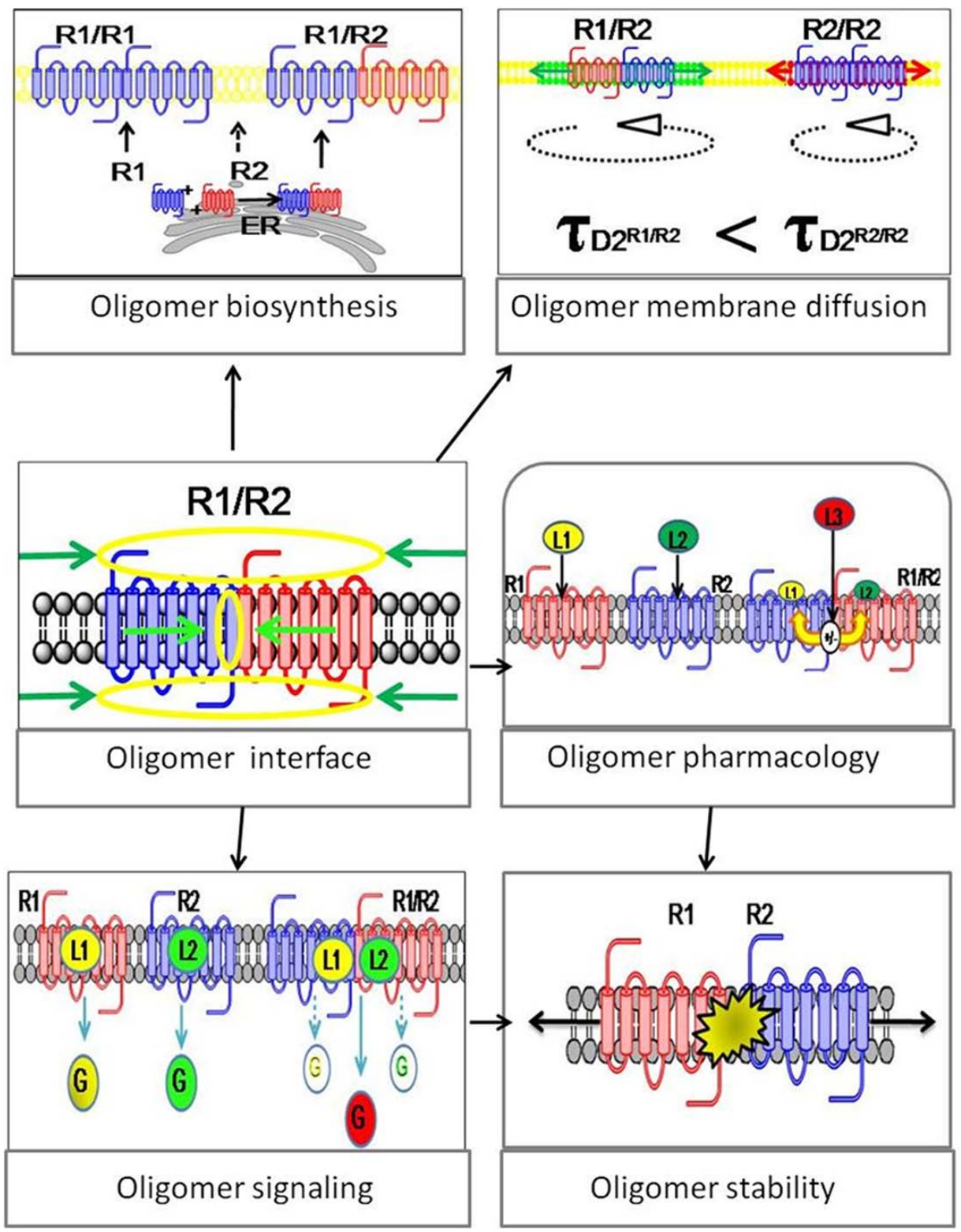

Fig. (1). Role of oligomerization in the GPCR biology. Schematic representation highlighting some of the main themes connected to the concept of GPCR oligomerization. Both transmembrane and intra and extraceullular domains are involved in the GPCR oligomer interface. It has been suggested that these oligomer interfaces may act as allosteric "check-points", modulating the information flow within a named GPCR oligomer [46], therefore playing a very important role in GPCR oligomer biology. Such roles, for example, include oligomer biosynthesis, membrane diffusion, pharmacology and signalling, as well as others. Ultimately, the stability of the oligomer will greatly depend on the behaviour of the oligomer interface dynamics, consequently, how these 'check-points' can be modulated by signals, for example allosteric modulators and phosphorylation events.

oligomers are at the cell surface they may be distributed in different plasma membrane domains, such as lipid rafts or caveolae and may also interact with other receptors. As described above, the rationale for GPCR oligomerization is mainly concerned with the modulation of receptor functionality. Related to this, the new unit made up of different receptors may be for example differently coupled to the signal transduction pathways, but it also may have acquired distinct characteristics, for instance concentration, association or mobility, in the plasma membrane that would affect key cellular functions [59]. The heterodimer formed by $A_{1} R$ and $\mathrm{A}_{2 \mathrm{~A}} \mathrm{R}$ was recently studied, as mentioned above, by combining the BiFC and FCS approaches [59]. The data obtained showed different plasma membrane diffusion coefficients when analyzing the results from individual cotransfected cells. Interestingly, the heterodimer formed by $A_{1} R$ and $A_{2 A} R$ diffused significantly faster than the respective homodimers, thus it had higher diffusion coefficients (D) and lower translational diffusion times $(\tau \mathrm{D} 2)(\mathrm{D}=5.6$ $\left.\times 10-9 \mathrm{~cm}^{2} / \mathrm{s}, \tau \mathrm{D} 2=12.9 \pm 1.1 \mathrm{~ms}\right)$ than homodimers $(\mathrm{D}=5.0$ and $4.8 \times 10-9 \mathrm{~cm}^{2} / \mathrm{s}$ and $\tau \mathrm{D} 2=14.5 \pm 1.5 \mathrm{~ms}$ and $15.0 \pm 1.3$ $m s$ for $A_{1} R$ and $A_{2 A} R$ homodimers, respectively) (Fig. 1). Hence, it seems likely that oligomerization may change the receptor's behavior, in terms of plasma membrane diffusion, a fact that could reflect either possible differences in their interaction with other proteins, such as cytoskeletal or 
scaffolding proteins, or different interactions with the lipid environment of the plasma membrane $[59,60]$.

\section{THE CELL SIGNALLING CAN BE MODULATED BY GPCR OLIGOMERIZATION?}

It has been demonstrated that GPCRs can mediate biological signals by stimulating nucleotide exchange in the heterotimeric $\mathrm{G}$ proteins $(\mathrm{G} \alpha \beta \gamma)$ after agonist challenge. Nowadays, investigators are trying to prove how the oligomerization of these receptors might impinge in the transduction process by which these receptors transmit this signal to $\mathrm{G}$ proteins. In addition, these oligomers might act as coincidence detectors that control the extent and specificity of G-protein coupling. Thus, in some circumstances there is a synergistic increase of the receptor-mediated signalling when both agonists are present and in others the components of the heterodimers can negatively interact, thus attenuating signalling relative to the respective homodimers (Fig. 1). Interestingly, these situations have been studied in the $\alpha_{1 \mathrm{~A}} \mathrm{AR}$ and $\alpha_{1 \mathrm{~B}} \mathrm{AR}$ heterodimer [61], the $\mathrm{M}_{2} \mathrm{R}$ and $\mathrm{M}_{3} \mathrm{R}$ heterodimer $[62]$ and the $\beta A R$ and $B_{2} R$ [63].

On the other hand, a loss of G-protein coupling following heterodimer formation for several GPCR oligomers has been observed, for instance the MOR and DOR heterodimer [64], the $\alpha_{2 \mathrm{a}} \mathrm{AR}$ and MOR heterodimer $[65,66]$, the $\mathrm{CCR}_{5}$ and $\mathrm{CCR}_{2}$ receptor heterodimer [67] and the $\mathrm{A}_{2 \mathrm{~A}} \mathrm{R}$ and $\mathrm{D}_{2} \mathrm{R}$ heterodimer (For review see [68]). Related to this, it has been demonstrated that the oligomerization change the nature of the interaction between the receptor and its associated G-protein (Fig. 1). For example, a change in the type of the $G$ protein used for signalling has been observed for the $D_{1} R / D_{2} R$ oligomer. Typically, the $D_{1} R$ couples to $G \alpha_{s / o l f}$ and the $D_{2} R$ to the $G \alpha_{i}$, but when these two receptors heterodimerize, $\mathrm{G \alpha}_{\mathrm{q} / 11 \text {-mediated signalling occurs, thus producing }}$ an increase in phospholipase $\mathrm{C}$ activity and a rapid rise in intracellular calcium levels without affecting adenylate cyclase activity regulated by $\mathrm{G \alpha}_{\mathrm{s} / \mathrm{olf}}$ and $\mathrm{G} \alpha_{\mathrm{i}}$. Interestingly, this oligomer-specific $G$ protein coupling requires the simultaneous activation of both $\mathrm{D}_{1} \mathrm{R}$ and $\mathrm{D}_{2} \mathrm{R}$ and it is regulated during brain development, thus being involved in synaptic plasticity [19]. Overall, a particular GPCR may exhibit variable $G$ protein coupling as a result of heterodimerization with diverse GPCR partners, thus generating an assortment of signalling phenotypes that greatly enrich the signal transduction process of a named receptor.

\section{GPCR OLIGOMERIZATION AND RECEPTOR PHARMACOLOGY}

It has been shown that the phenomenon of oligomerization of GPCRs permits more complex ligand-receptor interactions than those expected by the law of mass action and therefore expands the former concept of GPCRs being unique signalling units. The GPCR oligomer may alter receptor-agonist recognition by the formation of a new binding site with unique pharmacology (Fig. 1). For instance, it has been described that at the $\delta$-opioid receptor (DOR) and K-opioid receptor (KOR) heterodimer, 6'guanidinonaltrindole (6'-GNTI) acts as an agonist at the receptor but not at either homodimer [69], suggesting that this ligand represents a DOR/KOR oligomer-specific drug and demonstrating the pharmacological distinctiveness of the DOR/KOR oligomer. In addition to this, it has been shown that the 6'-GNTI has different effects depending on the administration site, thus spinal (but not central) administration leads to analgesia suggesting the need of a spatiotemporal synchronization i.e. of the GPCR oligomerization phenomena in order to achieve effective receptor oligomers. Thus, to achieve an effective oligomerization the respective protomers need to be expressed at the same time and at the same place. Similarly, another GPCR oligomer-specific drug has been described, namely SKF83959 for the $D_{1} R / D_{2} R$ heterodimer [19].

Jordan and Devi, in studies based on DOR and KOR ligand binding and functional experiments [70], studied the possible theory that GPCR oligomerization can play a key role in pharmacological diversity by promoting positive/ negative cooperativity within the protomers, forming a named oligomer. Although these two receptors oligomerize when coexpressed in the same cell, the heterodimer showed a very low affinity for either the $\delta$ - or the $\kappa$-selective ligand alone (i.e. [d-Pen ${ }^{2}$,d-Pen ${ }^{5}$ ]-enkephalin and U69593, respectively). Interestingly, high affinity for these ligands was restored following the simultaneous combination of these two compounds, thus suggesting the existence of a positive cooperativity [70]. On the other hand, GPCR oligomermediated ligand binding negative cooperativity has also been described (for review see [3]).

GPCR dimerization nowadays offers new opportunities for drug design and drug treatment. At least two strategies may be envisioned for GPCR heterodimers. Firstly, the coadministration of two conventional drugs, targeting each of the two GPCR protomers contained within the heterodimer, and secondly, development of monovalent heterodimerspecific compounds [71]). An example of such a compound is MDAN-18, which is composed of both oxymorphone, a MOR agonist, and by naltrindole, a DOR antagonist [72]. Interestingly, these drugs displayed a higher anti-nociceptive activity when compared to that achieved by co-administration of the two individual ligands [72]. Finally, a set of compounds with great pharmacological potential interest are those that affect the stability of the GPCR oligomer (Fig. 1). Indeed, by specifically targeting the oligomer interface with small molecule drugs (i.e. allosteric modulators) (Fig. 1) it might be possible to preclude these receptor functions associated with the oligomer (for review see [41]. Overall, the quaternary structure of the GPCRs determines their functionality, thus the control of the oligomer assembly/disassembly will be a powerful pharmacological tool.

\section{FUTURE CHALLENGES}

To conclude, the existence of GPCR oligomers has been largely demonstrated in heterologous expression systems where the respective protomers were often overexpressed, thus prompting the formation of artefacts (e.g. promotion or inhibition of protein-protein interactions). Related to this, it is believed that the GPCR oligomerization forms part of a cellular adaptive mechanism that increases the cell responsiveness in view of new environmental challenges. Thus, in order to fully understand the physiological relevance of this phenomenon, the real challenge consists in the in vivo 
determination of GPCR oligomers in both normal and pathological conditions. Interestingly, some hints about the significance of GPCR olgomerization in health and disease has been initially revealed, for instance the oligomerization of $\beta_{1}$ - and $\beta_{2}$ ARs in the heart may play a critical role in the overall response of the heart to stimuli. Thus, it is suggested that in a healthy heart the high $\beta_{1} \mathrm{AR}$ expression prevents growth-related signaling of $\beta_{2} \mathrm{ARs}$, whereas downregulation of $\beta$ ARs in response to excess of catecholamines may allow a previously blocked $\beta_{2} \mathrm{AR}$ signaling pathways to proceed (for review see [73]). Also, the angiotensin II type 1 receptor $\left(\mathrm{AT}_{1} \mathrm{R}\right)$ and the bradykinin $\mathrm{B}_{2}$ receptor $\left(\mathrm{B}_{2} \mathrm{R}\right)$ oligomer has been shown to be increased in preeclamptic hypertensive women and proposed to be behind the angiotensin IImediated increased vasoconstriction and hypertension [74]. Thus, the magnitude of GPCR oligomerization in health and disease will be revealed in a near future.

For the in vivo occurrence of GPCR oligomers the spatiotemporal synchronization of the receptor expression is very important (i.e. they should be transcribed and translated in the same place and at the same time). Interestingly, there is a hypothesis regarding the assembly of the heteromers in the ER/Golgi, making this area an important point in the heteromerization, where the oligomer interface should be properly folded and the "check-points" that regulate the flow of information between protomers are established. Only then can the GPCR oligomer travel to the plasma membrane where it will become fully functional (Fig. 1). Overall, from the pharmacological point of view the GPCR oligomerization phenomenon opens the door to more selective therapies with reduced side effects. Therefore, the pharmacological complexity added by the receptor oligomerization phenomenon will, in the next couple of years propel the search for new drugs acting on specific GPCR oligomers, but before this these oligomers must be identified in order to be properly targeted.

$$
\begin{aligned}
& \text { ABBREVIATIONS } \\
& \text { GPCR = G protein-coupled receptor } \\
& \mathrm{CCK}=\text { Cholecystokinin } \\
& \text { VIP = Vasoactive intestinal peptide } \\
& \text { NPY }=\text { Neuropeptide } Y \\
& \mathrm{NK}=\text { Neurokinin } \\
& \text { 5-HT }=5 \text {-Hydroxytryptamine or serotonin } \\
& \text { GABA }=\gamma \text {-Aminobutiric acid } \\
& \mathrm{mGlu}=\text { Metabotropic glutamate receptor } \\
& \mathrm{D}_{2} \mathrm{R}=\text { Dopamine } \mathrm{D}_{2} \text { receptor } \\
& \mathrm{A}_{2 \mathrm{~A}} \mathrm{R}=\text { Adenosine } \mathrm{A}_{2 \mathrm{~A}} \text { receptor } \\
& \mathrm{M}_{5} \mathrm{R}=\text { Muscarinic acetylcholine } \mathrm{M}_{5} \text { receptor } \\
& \text { DOR }=\delta \text {-Opioid receptor } \\
& \text { KOR }=\kappa \text {-Opioid receptor } \\
& \text { SDS- } \quad=\text { Sodium dodecyl sulfate polyacrylamide gel } \\
& \text { PAGE electrophoresis } \\
& \text { RET = Resonante energy transfer }
\end{aligned}
$$

$$
\begin{array}{ll}
\text { BRET } & =\text { Bioluminescence-RET } \\
\text { FRET } & =\text { Fluorescente-RET } \\
\text { BiFC } & =\text { Bimolecular fluorescence complementation } \\
\text { SRET } & =\text { Sequential-RET } \\
\mathrm{TM} & =\text { Transmembrane helix } \\
\mathrm{ER} & =\text { Endoplasmic reticulum } \\
\text { FCS } & =\text { Fluorescence correlation spectroscopy } \\
6 & \text { '-GNTI }
\end{array}
$$

\section{ACKNOWLEDGEMENTS}

This work was supported by grants SAF2008-01462 and Consolider-Ingenio CSD2008-00005 from Ministerio de Ciencia e Innovación and the ICREA Academia-2010 award from the Catalan Institution for Research and Advanced Studies to FC. The authors belong to the "Neuropharmacology and Pain" accredited research group (Generalitat de Catalunya, 2009 SGR 232).

\section{REFERENCES}

[1] Agnati LF, Fuxe K, Zini I, Lenzi P, Hokfelt T. Aspects on receptor regulation and isoreceptor identification. Med Biol 1980; 58: 1827.

[2] Maggi A, U'Prichard DC, Enna SJ. $\beta$-Adrenergic regulation of $\alpha_{2}$ adrenergic receptors in the central nervous system. Science 1980; 207: 645-7.

[3] Agnati LF, Ferre S, Lluis C, Franco R, Fuxe K. Molecular mechanisms and therapeutical implications of intramembrane receptor/receptor interactions among heptahelical receptors with examples from the striatopallidal GABA neurons. Pharmacol Rev 2003; 55: 509-50.

[4] Avissar S, Amitai G, Sokolovsky M. Oligomeric structure of muscarinic receptors is shown by photoaffinity labeling: subunit assembly may explain high- and low-affinity agonist states. Proc Natl Acad Sci U S A 1983; 80: 156-9.

[5] Fraser CM, Venter JC. The size of the mammalian lung $\beta_{2^{-}}$ adrenergic receptor as determined by target size analysis and immunoaffinity chromatography. Biochem Biophys Res Commun 1982; 109: 21-9.

[6] Peterson GL, Rosenbaum LC, Broderick DJ, Schimerlik MI. Physical properties of the purified cardiac muscarinic acetylcholine receptor. Biochemistry 1986; 25: 3189-202.

[7] Herberg JT, Codina J, Rich KA, Rojas FJ, Iyengar R. The hepatic glucagon receptor. Solubilization, characterization, and development of an affinity adsorption assay for the soluble receptor. J Biol Chem 1984; 259: 9285-94.

[8] Ng GY, George SR, Zastawny RL, et al. Human serotonin1B receptor expression in Sf9 cells: phosphorylation, palmitoylation, and adenylyl cyclase inhibition. Biochemistry 1993; 32: 11727-33.

[9] Ng GY, Mouillac B, George SR, Caron M, Dennis M, Bouvier M, O'Dowd BF. Desensitization, phosphorylation and palmitoylation of the human dopamine $\mathrm{D}_{1}$ receptor. Eur J Pharmacol 1994; 267: 7 19.

[10] Ng GY, O'Dowd BF, Caron M, Dennis M, Brann MR, George SR. Phosphorylation and palmitoylation of the human $\mathrm{D}_{2 \mathrm{~L}}$ dopamine receptor in Sf9 cells. J Neurochem 1994; 63: 1589-95.

[11] Ng GY, O'Dowd BF, Lee SP, Chung HT, Brann MR, Seeman P, George SR. Dopamine $\mathrm{D}_{2}$ receptor dimers and receptor-blocking peptides. Biochem Biophys Res Commun 1996; 227: 200-4.

[12] George SR, Lee SP, Varghese G, Zeman PR, Seeman P, Ng GY, O'Dowd BF. A transmembrane domain-derived peptide inhibits $\mathrm{D}_{1}$ dopamine receptor function without affecting receptor oligomerization. J Biol Chem 1998; 273: 30244-8.

[13] Zawarynski P, Tallerico T, Seeman P, Lee SP, O'Dowd BF, George SR. Dopamine $\mathrm{D}_{2}$ receptor dimers in human and rat brain. FEBS Lett 1998; 441: 383-6. 
[14] Ciruela F, Casado V, Mallol J, Canela EI, Lluis C, Franco R. Immunological identification of $\mathrm{A}_{1}$ adenosine receptors in brain cortex. J Neurosci Res 1995; 42: 818-28.

[15] Bouvier M. Oligomerization of G-protein-coupled transmitter receptors. Nat Rev Neurosci 2001; 2: 274-86.

[16] Franco R, Canals M, Marcellino D, Ferre S, Agnati L, Mallol J, Casado V, Ciruela F, Fuxe K, Lluis C, Canela EI. Regulation of heptaspanning-membrane-receptor function by dimerization and clustering. Trends Biochem Sci 2003; 28: 238-43.

[17] Milligan G, Bouvier M. Methods to monitor the quaternary structure of G protein-coupled receptors. FEBS J 2005; 272: 291425.

[18] Pfleger KD, Eidne KA. Illuminating insights into protein-protein interactions using bioluminescence resonance energy transfer (BRET). Nat Methods 2006; 3: 165-74.

[19] Rashid AJ, So CH, Kong MM, Furtak T, El-Ghundi M, Cheng R, O'Dowd BF, George SR. $\mathrm{D}_{1}-\mathrm{D}_{2}$ dopamine receptor heterooligomers with unique pharmacology are coupled to rapid activation of $\mathrm{G}_{q / 11}$ in the striatum. Proc Natl Acad Sci U S A 2007; 104: 654-9.

[20] Juhasz JR, Hasbi A, Rashid AJ, So CH, George SR, O'Dowd BF. $\mu$-opioid receptor heterooligomer formation with the dopamine $\mathrm{D}_{1}$ receptor as directly visualized in living cells. Eur J Pharmacol 2008; 581: 235-43.

[21] Carriba P, Navarro G, Ciruela F, Ferre S, Casado V, Agnati L, Cortes A, Mallol J, Fuxe K, Canela EI, Lluis C, Franco R. Detection of heteromerization of more than two proteins by sequential BRET-FRET. Nat Methods 2008; 5: 727-33.

[22] Gandia J, Galino J, Amaral OB, Soriano A, Lluis C, Franco R, Ciruela F. Detection of higher-order $G$ protein-coupled receptor oligomers by a combined BRET-BiFC technique. FEBS Lett 2008; 582: 2979-84.

[23] Dupre DJ, Robitaille M, Ethier N, Villeneuve LR, Mamarbachi AM, Hebert TE. Seven transmembrane receptor core signaling complexes are assembled prior to plasma membrane trafficking. J Biol Chem 2006; 281: 34561-73.

[24] Guo W, Urizar E, Kralikova M, Mobarec JC, Shi L, Filizola M, Javitch JA. Dopamine $\mathrm{D}_{2}$ receptors form higher order oligomers at physiological expression levels. EMBO J 2008; 27: 2293-304.

[25] Lopez-Gimenez JF, Canals M, Pediani JD, Milligan G. The $\alpha_{1 b}$ adrenoceptor exists as a higher-order oligomer: effective oligomerization is required for receptor maturation, surface delivery, and function. Mol Pharmacol 2007; 71: 1015-29.

[26] Navarro G, Carriba P, Gandia J, Ciruela F, Casado V, Cortes A, Mallol J, Canela EI, Lluis C, Franco R. Detection of heteromers formed by cannabinoid $\mathrm{CB}_{1}$, dopamine $\mathrm{D}_{2}$, and adenosine $\mathrm{A}_{2 \mathrm{~A}} \mathrm{G}$ protein-coupled receptors by combining bimolecular fluorescence complementation and bioluminescence energy transfer. Sci World J 2008; 8: 1088-97.

[27] Vidi PA, Chen J, Irudayaraj JM, Watts VJ. Adenosine $\mathrm{A}_{2 \mathrm{~A}}$ receptors assemble into higher-order oligomers at the plasma membrane. FEBS Lett 2008; 582: 3985-90.

[28] Chabre M, Cone R, Saibil H. Biophysics: is rhodopsin dimeric in native retinal rods? Nature 2003; 426: 30,1; discussion 31 .

[29] White JH, Wise A, Main MJ, Green A, Fraser NJ, Disney GH, Barnes AA, Emson P, Foord SM, Marshall FH. Heterodimerization is required for the formation of a functional $G_{A B A}$ receptor. Nature 1998; 396: 679-82.

[30] Fotiadis D, Jastrzebska B, Philippsen A, Muller DJ, Palczewski K, Engel A. Structure of the rhodopsin dimer: a working model for G protein-coupled receptors. Curr Opin Struct Biol 2006; 16: 252-9.

[31] Hebert TE, Moffett S, Morello JP, Loisel TP, Bichet DG, Barret C, Bouvier M. A peptide derived from a $\beta 2$-adrenergic receptor transmembrane domain inhibits both receptor dimerization and activation. J Biol Chem 1996; 271: 16384-92.

[32] Lee SP, O'Dowd BF, Rajaram RD, Nguyen T, George SR. D dopamine receptor homodimerization is mediated by multiple sites of interaction, including an intermolecular interaction involving transmembrane domain 4. Biochemistry 2003; 42: 11023-31.

[33] Guo W, Shi L, Javitch JA. The fourth transmembrane segment forms the interface of the dopamine $\mathrm{D}_{2}$ receptor homodimer. J Biol Chem 2003; 278: 4385-8.

[34] Guo W, Shi L, Filizola M, Weinstein H, Javitch JA. Crosstalk in G protein-coupled receptors: changes at the transmembrane homodimer interface determine activation. Proc Natl Acad Sci U S A 2005; 102: 17495-500.
[35] Mancia F, Assur Z, Herman AG, Siegel R, Hendrickson WA. Ligand sensitivity in dimeric associations of the serotonin $5 \mathrm{HT}_{2 \mathrm{c}}$ receptor. EMBO Rep 2008; 9: 363-9.

[36] Berthouze M, Rivail L, Lucas A, Ayoub MA, Russo O, Sicsic S, Fischmeister R, Berque-Bestel I, Jockers R, Lezoualc'h F. Two transmembrane Cys residues are involved in $5-\mathrm{HT}_{4}$ receptor dimerization. Biochem Biophys Res Commun 2007; 356: 642-7.

[37] Hernanz-Falcon P, Rodriguez-Frade JM, Serrano A, et al. Identification of amino acid residues crucial for chemokine receptor dimerization. Nat Immunol 2004; 5: 216-23.

[38] Wang HXKonopka JB. Identification of amino acids at two dimer interface regions of the alpha-factor receptor (Ste2). Biochemistry 2009; 48: 7132-9.

[39] Mikhailova MV, Blansett J, Jacobi S, Mayeux PR, Cornett LE. Transmembrane domain IV of the Gallus gallus VT2 vasotocin receptor is essential for forming a heterodimer with the corticotrophin releasing hormone receptor. J Biomed Opt 2008; 13 : 031208 .

[40] Gonzalez-Maeso J, Ang RL, Yuen T, et al. Identification of a serotonin/glutamate receptor complex implicated in psychosis. Nature 2008; 452: 93-7.

[41] Filizola M. Increasingly accurate dynamic molecular models of G protein-coupled receptor oligomers: Panacea or Pandora's box for novel drug discovery? Life Sci 2010; 86: 590-7.

[42] Fonseca JM, Lambert NA. Instability of a class a G protein-coupled receptor oligomer interface. Mol Pharmacol 2009; 75: 1296-9.

[43] Ciruela F, Burgueno J, Casado V, et al. Combining mass spectrometry and pull-down techniques for the study of receptor heteromerization. Direct epitope-epitope electrostatic interactions between adenosine $\mathrm{A}_{2 \mathrm{~A}}$ and dopamine $\mathrm{D}_{2}$ receptors. Anal Chem 2004; 76: 5354-63.

[44] Borroto-Escuela DO, Marcellino D, Narvaez M, et al. A serine point mutation in the adenosine $\mathrm{A}_{2 \mathrm{~A}} \mathrm{R}$-terminal tail reduces receptor heteromerization and allosteric modulation of the dopamine $\mathrm{D}_{2} \mathrm{R}$. Biochem Biophys Res Commun 2010; 394: 222-7.

[45] Borroto-Escuela DO, Garcia-Negredo G, Garriga P, Fuxe K, Ciruela $\mathrm{F}$. The $\mathrm{M}_{5}$ muscarinic acetylcholine receptor third intracellular loop regulates receptor function and oligomerization. Biochim Biophys Acta 2010; 1803: 813-25.

[46] Agnati LF, Guidolin D, Leo G, Carone C, Genedani S, Fuxe K. Receptor-receptor interactions: A novel concept in brain integration. Prog Neurobiol 2010; 90: 157-75.

[47] Petaja-Repo UE, Hogue M, Laperriere A, Walker P, Bouvier M. Export from the endoplasmic reticulum represents the limiting step in the maturation and cell surface expression of the human delta opioid receptor. J Biol Chem 2000; 275: 13727-36.

[48] Petaja-Repo UE, Hogue M, Laperriere A, Bhalla S, Walker P, Bouvier M. Newly synthesized human delta opioid receptors retained in the endoplasmic reticulum are retrotranslocated to the cytosol, deglycosylated, ubiquitinated, and degraded by the proteasome. J Biol Chem 2001; 276: 4416-23.

[49] Reddy PS, Corley RB. Assembly, sorting, and exit of oligomeric proteins from the endoplasmic reticulum. Bioessays 1998; 20: 54654.

[50] Jones KA, Borowsky B, Tamm JA, Craig DA, Durkin MM, Dai M, Yao WJ, Johnson M, Gunwaldsen C, Huang LY, Tang C, Shen Q, Salon JA, Morse K, Laz T, Smith KE, Nagarathnam D, Noble SA, Branchek TA, Gerald C. $\mathrm{GABA}_{\mathrm{B}}$ receptors function as a heteromeric assembly of the subunits $G_{A B A} R 1$ and $G_{B B A} R 2$. Nature 1998; 396: 674-9.

[51] Kaupmann K, Schuler V, Mosbacher J, Bischoff S, Bittiger H, Heid J, Froestl W, Leonhard S, Pfaff T, Karschin A, Bettler B. Human gamma-aminobutyric acid type $B$ receptors are differentially expressed and regulate inwardly rectifying $\mathrm{K}^{+}$ channels. Proc Natl Acad Sci U S A 1998; 95: 14991-6.

[52] Kuner R, Kohr G, Grunewald S, Eisenhardt G, Bach A, Kornau $\mathrm{HC}$. Role of heteromer formation in $\mathrm{GABA}_{\mathrm{B}}$ receptor function. Science 1999; 283: 74-7.

[53] Kaupmann K, Huggel K, Heid J, et al. Expression cloning of $\mathrm{GABA}_{\mathrm{B}}$ receptors uncovers similarity to metabotropic glutamate receptors. Nature 1997; 386: 239-46.

[54] Bowery NG, Brown DA. The cloning of GABA B $_{B}$ receptors. Nature 1997; 386: 223-4.

[55] Isomoto S, Kaibara M, Sakurai-Yamashita Y, Nagayama Y, Uezono Y, Yano K, Taniyama K. Cloning and tissue distribution of 
novel splice variants of the rat $\mathrm{GABA}_{\mathrm{B}}$ receptor. Biochem Biophys Res Commun 1998; 253: 10-5.

[56] Pfaff $\mathrm{T}$, Malitschek B, Kaupmann K, et al. Alternative splicing generates a novel isoform of the rat metabotropic $\mathrm{GABA}_{\mathrm{B}} \mathrm{R} 1$ receptor. Eur J Neurosci 1999; 11: 2874-82.

[57] Filippov AK, Couve A, Pangalos MN, Walsh FS, Brown DA, Moss SJ. Heteromeric assembly of $\mathrm{GABA}_{\mathrm{B}} \mathrm{R} 1$ and $\mathrm{GABA}_{\mathrm{B}} \mathrm{R} 2$ receptor subunits inhibits $\mathrm{Ca}^{2+}$ current in sympathetic neurons. J Neurosci 2000; 20: 2867-74.

[58] Schwarz DA, Barry G, Eliasof SD, Petroski RE, Conlon PJ, Maki RA. Characterization of gamma-aminobutyric acid receptor $\mathrm{GABA}_{\mathrm{Bl}}$, a $\mathrm{GABA}_{\mathrm{B} 1}$ splice variant encoding a truncated receptor. J Biol Chem 2000; 275: 32174-81.

[59] Briddon SJ, Gandia J, Amaral OB, et al. Plasma membrane diffusion of $\mathrm{G}$ protein-coupled receptor oligomers. Biochim Biophys Acta 2008; 1783: 2262-8.

[60] Briddon SJ, Hill SJ. Pharmacology under the microscope: the use of fluorescence correlation spectroscopy to determine the properties of ligand-receptor complexes. Trends Pharmacol Sci 2007; 28: 637-45.

[61] Israilova M, Tanaka T, Suzuki F, Morishima S, Muramatsu I. Pharmacological characterization and cross talk of $\alpha_{1 a^{-}}$and $\alpha_{1 b^{-}}$ adrenoceptors coexpressed in human embryonic kidney 293 cells. J Pharmacol Exp Ther 2004; 309: 259-66.

[62] Hornigold DC, Mistry R, Raymond PD, Blank JL, Challiss RA. Evidence for cross-talk between $M_{2}$ and $M_{3}$ muscarinic acetylcholine receptors in the regulation of second messenger and extracellular signal-regulated kinase signalling pathways in Chinese hamster ovary cells. Br J Pharmacol 2003; 138: 1340-50.

[63] Hanke S, Nurnberg B, Groll DH, Liebmann C. Cross talk between beta-adrenergic and bradykinin $\mathrm{B}_{2}$ receptors results in cooperative regulation of cyclic AMP accumulation and mitogen-activated protein kinase activity. Mol Cell Biol 2001; 21: 8452-60.

[64] Charles AC, Mostovskaya N, Asas K, Evans CJ, Dankovich ML, Hales TG. Coexpression of $\delta$-opioid receptors with micro receptors in $\mathrm{GH}_{3}$ cells changes the functional response to micro agonists from inhibitory to excitatory. Mol Pharmacol 2003; 63: 89-95.

[65] Jordan BA, Gomes I, Rios C, Filipovska J, Devi LA. Functional interactions between mu opioid and $\alpha_{2 \mathrm{~A}}$-adrenergic receptors. Mol Pharmacol 2003; 64: 1317-24.

[66] Vilardaga JP, Nikolaev VO, Lorenz K, Ferrandon S, Zhuang Z, Lohse MJ. Conformational cross-talk between $\alpha_{2 \mathrm{~A}}$-adrenergic and $\mu$-opioid receptors controls cell signaling. Nat Chem Biol 2008; 4: 126-31.

[67] Mellado M, Rodriguez-Frade JM, Vila-Coro AJ, et al. Chemokine receptor homo- or heterodimerization activates distinct signaling pathways. EMBO J 2001; 20: 2497-507.

[68] Fuxe K, Marcellino D, Guidolin D, Woods AS, Agnati LF. Heterodimers and receptor mosaics of different types of G-proteincoupled receptors. Physiology (Bethesda) 2008; 23: 322-32.

[69] Waldhoer M, Fong J, Jones RM, et al. A heterodimer-selective agonist shows in vivo relevance of $\mathrm{G}$ protein-coupled receptor dimers. Proc Natl Acad Sci U S A 2005; 102: 9050-5.

[70] Jordan BA, Devi LA. G-protein-coupled receptor heterodimerization modulates receptor function. Nature 1999; 399: 697-700.

[71] Berque-Bestel I, Lezoualc'h F, Jockers R. Bivalent ligands as specific pharmacological tools for $\mathrm{G}$ protein-coupled receptor dimers. Curr Drug Discov Technol 2008; 5: 312-8.

[72] Daniels DJ, Lenard NR, Etienne CL, Law PY, Roerig SC, Portoghese PS. Opioid-induced tolerance and dependence in mice is modulated by the distance between pharmacophores in a bivalent ligand series. Proc Natl Acad Sci U S A 2005; 102: 19208-13.

[73] Barki-Harrington L, Perrino C, Rockman HA. Network integration of the adrenergic system in cardiac hypertrophy. Cardiovasc Res 2004; 63: 391-402.

[74] AbdAlla S, Lother H, el Massiery A, Quitterer U. Increased $\mathrm{AT}_{1}$ receptor heterodimers in preeclampsia mediate enhanced angiotensin II responsiveness. Nat Med 2001; 7: 1003-9. 